\title{
Dentists Perspective Regarding Prophylactic Removal Of Asymptomatic And Impacted Third Molars
}

Wahab Buksh Kadri, Sameera Asif, Atif Zubairi, Sarah Jamil, Tooba Kamran, Zahra Hassan, Hania Idrees

ABSTRACT:

Objective: To determine dentist's perspective regarding NHS guidelines for prophylactic removal of Impacted Third molars among dentists of Karachi.

Study Design and Setting: It was a cross sectional study design based on the questionnaire. Questionnaire was filled by total 110 general dentists selected by random sampling and was practicing in various private and government setups of Karachi to know about their preference regarding prophylactic removal of asymptomatic third molar.

Methodology:The questionnaire comprised of total 13 questions to find out dentists view point about the prophylactic removal of impacted third molar. The results were then analyzed using SPSS version 23. Frequencies, percentages of different variables used in the study were calculated to identify the co-relation among different attributes. P-value of less than or equal to 0.05 was considered statistically significant.

Results: The study reflected that $71.8 \%$ dentists were aware with the NHS Guidelines for removal of asymptomatic \& impacted third molars while $28.2 \%$ dentists preferred conventional approach. The study also revealed Mesioangular impaction as being the most commonly observed type of impaction in the dental practice.

Conclusion: It was concluded from this study that majority of dentists were aware of the guidelines provided by NHS and regarding the angulation of impacted teeth most of the impactions seen at the dental office were Mesioangular.

Key Words: Asymptomatic tooth, Impacted third molar NHS guidelines, Prophylactic tooth removal.

\section{INTRODUCTION:}

Mandibular third molars are the most frequently encountered teeth which are impacted in human dentition. ${ }^{1}$ Prophylactic removal of asymptomatic tooth is defined as the removal of tooth without any sign and symptoms in order to prevent occurrence of disease or pathology. ${ }^{2}$ Impacted lower third molars are commonly removed surgically in general dental

\begin{tabular}{|c|}
\hline $\begin{array}{l}\text { Wahab Buksh Kadri, } \\
\text { Head of Dept., Oral \& Maxillofacial Surgery } \\
\text { Bahria University Medical and Dental College }\end{array}$ \\
\hline $\begin{array}{l}\text { Sameera Asif, } \\
\text { Senior Registrar, Oral \& Maxillofacial Surgery, } \\
\text { Bahria University Medical and Dental College } \\
\text { Email:sameeraasif3@gmail.com }\end{array}$ \\
\hline $\begin{array}{l}\text { Atif Zubairi, } \\
\text { Senior Lecturer, Oral \& Maxillofacial Surgery } \\
\text { Bahria University Medical and Dental College }\end{array}$ \\
\hline $\begin{array}{l}\text { Sarah Jamil, } \\
\text { House Officer } \\
\text { Bahria University Medical and Dental College }\end{array}$ \\
\hline $\begin{array}{l}\text { Tooba Kamran, } \\
\text { House Officer } \\
\text { Bahria University Medical and Dental College }\end{array}$ \\
\hline $\begin{array}{l}\text { Zahra Hassan, } \\
\text { House Officer } \\
\text { Bahria University Medical and Dental College }\end{array}$ \\
\hline $\begin{array}{l}\text { Hania Idrees } \\
\text { House Officer } \\
\text { Bahria University Medical and Dental College }\end{array}$ \\
\hline
\end{tabular}

practice as well as many teaching institutions. Even though there are well demarcated indications for the removal of impacted third molars, still their removal without a concurrent disease is being carried out universally. ${ }^{3,4}$ In many studies, removal of asymptomatic impacted teeth have proven to reduce the pathologies associated with partially erupted or impacted third molars. ${ }^{4,5}$ The indications behind removal of third molars have always been a matter of controversy among the dental practitioners. In the previous years, many dental practitioners have come to a conclusion that asymptomatic third molars should be extracted to counter the risks and complications that follow. ${ }^{6,7}$

Third molar removal is one of the most prevalent surgeries performed in Oral Surgery. The rationale being is the high trend of their impactions, often linked to various problems in the oral cavity, such as pericoronitis, periodontal deficiencies in the distal margins of second molar, numerous types of odontogenic cysts and tumours, and overlapping of the incisors of lower jaw. ${ }^{8,9,10}$

Current NHS Guidelines recommended that healthy wisdom teeth should not be removed as a preventive measure, unless there is an 'evidence of repeated infection or disease associated with the tooth. ${ }^{11}$ In order to devise a comprehensive treatment plan, dentist must take into account all the factors that may impact the outcome of their treatment. ${ }^{9}$ Concurrently, risk vs. benefit analysis should also be done to justify these surgeries. ${ }^{12,13}$

Additionally, both the dentists and their patients must consider the drawbacks related to the surgical procedure. These 
drawbacks range from pain to bleeding, dry socket to dehiscence, abscesses, paresthesia, hematoma and trismus. Severe trauma during surgery may lead to fractures of the jaw. ${ }^{11}$ Therefore, decisions regarding removal and retention should be done wisely according to the available guidelines on prophylactic removal of Impacted Third Molars. The objective of the study was to determine dentist's perspective regarding NHS guidelines for prophylactic removal of Impacted Third molars among dentists of Karachi.

METHODOLOGY: This cross sectional study was conducted over a period of 3 months from the time of approval in Bahria University Medical \& Dental College, Karachi.The instrument to record responses was formulated on the basis of 13 close-ended questions. The interrogated questions were rate of third molar extraction, the philosophy behind the third molar extraction, the type of impaction recommended for extraction, most common age group recommended for extraction, consequences of retaining 3rd molars, the conditions that justify your recommendation of extractions and awareness regarding the NHS guidelines for extraction of wisdom tooth along with the demographic questions which were type of clinical practice, professional experience and location of practice.. Participants were randomly selected via convenience sampling. Total 118 dentists included in the study but due to incomplete questionnaire 8 forms were excluded hence responses of 110 dentists were analyzed for this study. Ethical permission was obtained from the Ethical Review Committee of Bahria University Medical \& Dental College before the data collection. Written consent was obtained from the participants before filling the form. Only practicing dentists were included in the study, with age range of 25-65 years. Fresh graduates and house officers were excluded from the study. Data was analyzed using SPSS ver.23. Frequencies, percentages of different variables used in the study were calculated to identify the co-relation via Fisher Exact test.

\section{RESULTS:}

From the total 110 dentists $71.8 \%$ showed awareness to NHS guidelines for third molar removal cases, while $28.2 \%$ of dentists preferred the conventional approach of third molar removal in asymptomatic and impacted third molar cases. It was observed that mesioangular impactions are the most commonly removed impaction in private and hospital settings. (Table 1) followed by distoangular, horizontal and vertical impactions respectively. Regarding consequences of retaining third molar, study revealed that chances of development of cyst and tumors associated with third molar are more prevalent, if the impacted tooth is not removed followed by tooth decay which can pose significant risk to patient's health and hygiene.(Table 1).

Regarding the correlation between awareness of dentists with NHS Guidelines and Justification of removal of impacted third molar, it was observed that pathologies associated with third molar were a major concern while planning for removal of impacted third molar followed by recurrent pericoronitis. (Table 2). However, results revealed that awareness of these guidelines did not impart any significant difference among the treatment planning. (P-value: 0.164)

Table-1: Awareness Of NHS Guidelines

\begin{tabular}{|l|c|}
\hline & Frequency (\%) \\
\hline Yes & $79(71.8 \%)$ \\
\hline No & $31(28.2 \%)$ \\
\hline $\begin{array}{l}\text { Type Of Impactions to which you recommend } \\
\text { Extractions }\end{array}$ & \\
\hline Mesioangular & $57(51.8 \%)$ \\
\hline Distoangular & $23(20.9 \%)$ \\
\hline Vertical & $14(12.7 \%)$ \\
\hline Horizontal & $16(14.5 \%)$ \\
\hline Consequences of Retaining 3rd Molars & \\
\hline Tooth decay & $27(24.5 \%)$ \\
\hline Bone loss & $15(13.6 \%)$ \\
\hline Interference with needed dental treatment & $12(10.9 \%)$ \\
\hline Periodontal Disease & $23(20.9 \%)$ \\
\hline Development of Associated cysts and tumors & $33(30.1 \%)$ \\
\hline
\end{tabular}

Table 2: Fisher exact test was applied to see the significance. $\mathrm{P}=$ 0.05 considered to be statistically significant

\begin{tabular}{|l|cc|c|c|}
\hline \multirow{2}{*}{$\begin{array}{l}\text { Condition that justify } \\
\text { your recommendation } \\
\text { of Extractions }\end{array}$} & \begin{tabular}{|}
$|c|$ \\
Awareness Of NHS \\
Guidelines
\end{tabular} & \multirow{2}{*}{ Total } & \multirow{2}{*}{ P-Value } \\
\cline { 2 - 3 } & Yes (\%) & No(\%) & & \\
\hline Recurrent Pericoronitis & $25(61 \%)$ & $16(39 \%)$ & 41 & \\
\hline $\begin{array}{l}\text { Periodontal Defects in } \\
\text { Second Molar }\end{array}$ & $9(75 \%)$ & $3(25 \%)$ & 12 & \\
\hline $\begin{array}{l}\text { Caries in 3rd or 2nd } \\
\text { Molar }\end{array}$ & $15(68.2 \%)$ & $7(31.8 \%)$ & 22 & \multirow{2}{*}{0.164} \\
\cline { 1 - 2 } $\begin{array}{l}\text { Associated Pathologies } \\
\text { with 3rd Molars }\end{array}$ & $28(87.5 \%)$ & $4(12.5 \%)$ & 32 & \\
\hline Crowding of Incisors & $2(66.7 \%)$ & $1(33.3 \%)$ & 3 & \\
\hline Total & $79(71.8 \%)$ & $31(28.2 \%)$ & 110 & \\
\hline
\end{tabular}

\section{DISCUSSION:}

The prophylactic surgery of $3^{\text {rd }}$ molar removal is defined as the surgical extraction of third molar in the absence of a disease at its particular site. ${ }^{2}$ During the course of this study, $71.8 \%$ of the dentist showed awareness to NHS guideline. However, no significant association was seen between the awareness of guidelines and removal of impacted teeth. In this view, The National Institute for Health and Clinical Excellence (NICE) issued guidance on the management of third molars in $2000 .{ }^{14}$ The stated guideline summarized that $40 \%$ of the wisdom teeth at NHS are removed without any clinical indication of extraction thus the practice of prophylactic extraction of wisdom teeth should be discontinued. Contrary to the guideline published, removal of impacted teeth is seen as commonly performed procedure in oral surgery. 
During the study, $51.8 \%$ of the patient showed Mesioangular positioned teeth followed by Distoangular, Horizontal and vertical impactions respectively. This finding was in agreement with a study conducted by $\mathrm{M}$ Hatem et $\mathrm{al}^{15}$ which stated that mesioangular impaction is the most prevalent angulation seen in mandibular impacted teeth. Regarding the consequence of retaining third molar, it was revealed that occurrence of pathological changes including development of cyst and tumor was seen in the retained impacted tooth (30.1\%) followed by caries to second molar (24.5\%). Various authors have assured that partially erupted molars are more prone to developing pericoronitis and are therefore best chosen for prophylactic removal..$^{910}$ Manganaro ${ }^{16}$ demonstrated similar findings, with cystic changes reported in nearly $46 \%$ of pericoronal radiolucencies around impacted third molar teeth. Several recent studies have evaluated soft tissues retrieved from third molar sites without radiographic evidence of disease (follicular spaces $3 \mathrm{~mm}$ or less), and have reported pathologic change in high percentages ${ }^{17,18}$, which was in accordance with the findings of our study.

Development of caries distal to second molar was also evident in patients presenting with partially impacted third molar according to this study. Allen et $\mathrm{a}^{19}$ described that caries on distal margins of second molars is more prevalent in second molars that are adjacent to partially erupted third molars. Nunn et $\mathrm{al}^{20}$ have proved in a clear set of words that retention of third molars is directly linked to increased risk of pathologies in middle aged population. The consequences of retaining third molar should be analyzed before formulating treatment plan. ${ }^{21,22}$ Development of cysts, tumors, tooth decay and periodontal issues are the most commonly considered factors which necessitates the removal of impacted wisdom teeth. ${ }^{23-27}$ Studies have also proven that with age, complications related to third molar surgeries increase significantly. ${ }^{26,28-30}$ Hence, treatment should be planned accordingly taking into account patient's age and medical status.

Among the limitations of the study larger sample size should be conducted to rule out the problems associated with impacted teeth. Clinical and radiographic parameters can also be included for in-depth analysis of effects caused by impacted and asymptomatic third molar in future studies.

CONCLUSION: The study concludes that majority of dentists were aware of the guidelines provided by NHS and regarding the angulation, mesioangular impaction was the most commonly seen impaction at the dental office.

\section{REFERENCES:}

1. Adeyemo WL, Ogunlewe MO, Ladeinde AL, Abib GT et al. Prevalence and surgical morbidity of impacted mandibular third molar removal in the aging population: a retrospective study at the Lagos University Teaching Hospital. Afr J Med Sci, 2006;35(4):479-483.
2. WasiuLanreAdeyemo. Do pathologies associated with impacted lower third molars justify prophylactic removal? A critical review of the literature. Elsevier 2006;102(4):448452.

3. GintarasJuodzbalys, PovilasDaugelaAlling CC, Mandibular Third Molar Impaction: Review of Literature and a Proposal of a Classification. J Oral Maxillofac Res. 2013;4(2).

4. Marciani RD. Complications of third molar surgery and their management. Atlas Oral MaxillofacSurgClin North Am. 2012;20(2):233-51.

5. SaifRaufSiddiqui, SuyashAgrawal, Harjeet Singh Monga, Abhishek Gaur. Prophylactic Removal of the Third Molars: Justified or Not. JIOH.2015;7(11):132-35.

6. Mimoza E. Selmani,JulijanaGjorgova,Manushaqe E. Selmani et al. Effects of Lower Third Molar Angulation and Position on Lower Arch Crowding. Int J Orthod. 2016; 27(1):45-49.

7. B. Krishnan,Mohammad Hossni El Sheikh, El-GehaniRafaand H. Orafi. Indications for removal of impacted mandibular third molars: a single institutional experience in Libya. $\mathrm{J}$ Maxillofac Oral Surg. 2009;8(3):246-248.

8. Laskin D. Evaluation of the third molar problem. J Am Dent Assoc 1971; 82: 824-9.

9. Costa MG, Pazzini CA, Pantuzo MC, Jorge ML,. Is there justification for prophylactic extraction of third molars? A systematic review. Braz. Oral Res. 2013; 27(2): 183-188.

10. Normando, David. "Third Molars: To Extract or Not to Extract?" Dental Press J Orthod. 2015:17-18.

11. L. W. McArdle\& T. Renton. The effects of NICE guidelines on the management of third molar teeth. Br Dent J. 2012;213(8):394.

12. Cutilli T, Bourelaki T, Scarsella S, Fabio DD, Pontecorvi E, Cargini P. Pathological (late) fractures of the mandibular angle after lower third molar removal: a case series. J Med Case Rep. 2013;7:121-121.

13. Divya.T et al. Third Molar Impaction- A Review. J. Pharm. Sci. \& Res. 2014; 6(11): 363-367.

14. National Institute for Clinical Excellence. Guidance on the extraction of wisdom teeth. London: NICE, 2000. Online article available at http://egap.evidence.nhs.uk/guidance-onthe-extraction-of-wisdom-teeth-tal (accessed August 2012)

15. MarwaHatemImanBugaighisElsanousiM.Taher. Pattern of third molar impaction in Libyan population: A retrospective radiographic study. Saudi J. Oral. Dent. Res. 2016;7(1):7-12.

16. Manganaro AM. The likelihood of finding occulthistopathology in routine third molar extractions.Gen Dent 1998;46:200-2

17. Mesgarzadeh AH, Esmailzadeh $\mathrm{H}$, Abdolrahimi $\mathrm{M}$ et al. Pathosis associated with radiographicallynormal follicular tissues in third molar impactions.Indian J Dent Res 2008;19:208-12.

18. Kotrashetti VS, Kale AD, Bhalaerao SS, et al. Histopathologic changes in soft tissue associated withradiographically normal impacted third molars.Indian J Dent Res 2010;21:385-90.

19. Allen RT, Witherow H, Collyer J, Roper-Hall R, Nazir MA, Mathew G (2009). The mesioangular third molar--to extract or not to extract? Analysis of 776 consecutive third molars. Br Dent J 206(11);E23:586-587

20. Nunn, ME, et al. Retained Asymptomatic Third Molars and Risk for Second Molar Pathology. J Dent Res. 2013 Oct. 
Wahab Buksh Kadri, Sameera Asif, Atif Zubairi, Sarah Jamil, Tooba Kamran, Zahra Hassan, Hania Idrees

21. Bui CH, Selodin EB, Dodson TB. Types, frequencies and risk factors for complications after third molar extraction. J Oral Maxillofac Surg. 2003; 61: 1379

22. Bouloux GF, Steed MB, and Perciaccante VJ. Complications of third molar surgery. Oral and Maxillofacial Surgery Clinics of North America. 2007; 19:117-128

23. Marciani RD. Third molar removal: An overview of indications, imaging, evaluation, and assessment of risk.. Oral and Maxillofacial Surgery Clinics of North America. 2007; 19:113

24. Blondeau F, Daniel NG. Extraction of impacted mandibular third molars: postoperative complications and their risk factors. J Can Dent Assoc. 2007;73(4):325.

25. Rood JP, Shehab BA. The radiological prediction of inferior alveolar nerve injury during third molar surgery. Br J Oral Maxillofac Surg. 1990;28(1):20-5.

26. Chuang SK, Perrott DH, Susarla SM, Dodson TB. Risk factors for inflammatory complications following third molar surgery in adults. J Oral Maxillofac Surg. 2008;66(11):2213-8.
27. Cheung LK, Leung YY, Chow LK, Wong MC, Chan EK, Fok $\mathrm{YH}$. Incidence of neurosensory deficits and recovery after lower third molar surgery: a prospective clinical study of 4338 cases. Int J Oral Maxillofac Surg. 2010;39(4):320-6. Epub 2010 Jan 12.

28. Renton T, Hankins M, Sproate C, McGurk M. A randomised controlled clinical trial to compare the incidence of injury to the inferior alveolar nerve as a result of coronectomy and removal of mandibular third molars. Br J Oral Maxillofac Surg. 2005;43(1):7-12.

29. Blakey GH, Marciani RD, Haug RH, Phillips C, Offenbacher S, Pabla T, et al. Periodontal pathology associated with asymptomatic third molars. J Oral MaxillofacSurg 2002;60(11):1227-33.

30. Adeyemo WL. Do pathologies associated with impacted lower third molars justify prophylactic removal? A critical review of the literature. Oral Surg Oral Med Oral Pathol Oral RadiolEndod 2006;102(4):448-52. 